
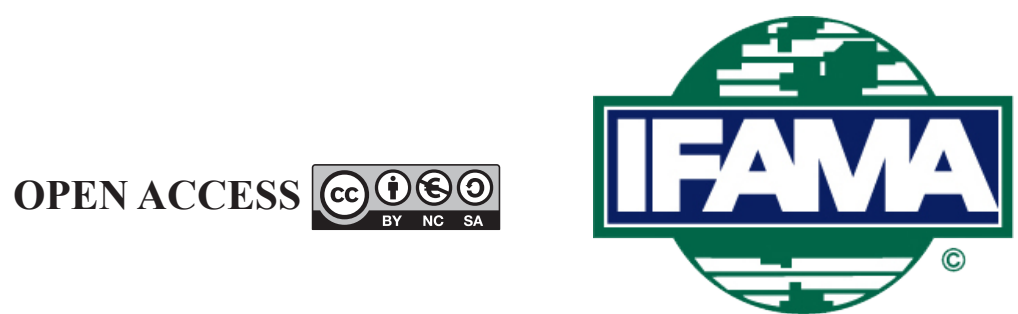

International Food and Agribusiness Management Review

Volume 24, Issue 4, 2021; DOI: 10.22434/IFAMR2020.0188

Received: 5 November 2020 / Accepted: 19 February 2021

Special Issue: Growth of agroholdings and mega-farms in transition and emerging market economies: institutional and organizational aspects

\title{
Post-acquisition integration and growth of farms: the case of Ukrainian agroholdings
}

RESEARCH ARTICLE

\author{
Igor Ostapchuk $^{(1)}$, Taras Gagalyuk ${ }^{\mathrm{b}}$ and Jarmila Curtiss ${ }^{\mathrm{c}, \mathrm{d}}$ \\ ${ }^{a}$ Research Associate, ${ }^{b}$ Senior Researcher, ${ }^{c}$ Visiting Research Fellow, Department of Structural \\ Development of Farms and Rural Areas, Leibniz Institute of Agricultural Development in \\ Transition Economies (IAMO), Theodor-Lieser-Strasse 2, 06120 Halle (Saale), Germany \\ ${ }^{d}$ Senior Researcher, Institute of Agriculture and Nutritional Sciences, Martin Luther \\ University Halle-Wittenberg, Von Seckendorff-Platz 4, 06120 Halle (Saale), Germany
}

\begin{abstract}
This paper presents a dynamic perspective on the processes of farm restructuring following farm acquisitions by large-scale agroholdings in Ukraine. In particular, the paper employs a large dataset of farm-level data and several quantitative techniques to explore how the acquired farms' resource bases are integrated after acquisitions and what outcomes an acquisition brings about for farm growth, profitability and productivity. In general, acquisitions positively affect farm growth and productivity while agroholdings use various resource allocation, resource redeployment and investment/divestment instruments for the post-acquisition integration of farms. The variation in achieving profitable post-acquisition growth of farms is contingent upon a number of farm pre-acquisition characteristics, strategic growth orientations and timing of acquisitions.
\end{abstract}

Keywords: acquisition waves, agroholdings, farm growth, post-acquisition integration, Ukraine JEL code: G34, L25, Q14

\footnotetext{
${ }^{\circledR}$ Corresponding author: ostapchuk@iamo.de
} 


\section{Introduction}

Over the past fifteen years, the development of agriculture in the former Soviet Union has been marked by the rise of so-called agroholdings (Hermans et al., 2017), which are very large, horizontally, and frequently vertically integrated farming entities that typically consist of a parent company that owns and hierarchically manages numerous subsidiary commercial farms (Gagalyuk and Valentinov, 2019; Koester, 2005). In countries such as Kazakhstan, Russia, and Ukraine, agroholdings are currently an important mode of organization of agricultural production along with other types of commercial farming that include standalone non-agroholding corporate farms and private, family or peasant farms ${ }^{1}$ (Lerman et al., 2007).

Research points to the following factors that drive agroholding development: a growing global demand for food (Hermans et al., 2017); inflows of external capital that led to growth via acquisitions of standalone farms (Gagalyuk and Valentinov, 2019; Petrick et al., 2013); reduction of country-specific transaction costs (Matyukha et al., 2015); and preferential public policies resulting from market power imbalances, lobbying and political objectives of self-sufficiency and export orientation of the domestic agri-food sectors (Gagalyuk et al., 2018). Some researchers suggest that agroholdings are able to improve their performance and decrease transaction costs through investments in modern technology and economies of size enabled by favorable access to external capital (Chaddad and Valentinov, 2017; Gagalyuk and Valentinov, 2019). Other studies have found that agroholdings tend to be less profitable than standalone farms (Balmann et al., 2013; Ostapchuk et al., 2019). However, a number of studies point to productivity deficits, high transaction costs and financial risks in agroholdings (Epshtein et al., 2013; Gagalyuk, 2017; Lapa et al., 2015).

Regardless of the mixed results, a key message of these studies is that agroholding farms do not seem to be more profitable than non-agroholding farms in general and thus form and grow (rapidly) despite being relatively inefficient. One of the potential reasons for inefficiencies in agroholdings is their rapid growth through the acquisition of standalone corporate farms (Mamonova, 2015). Few studies have focused on the outcomes of the acquisitive mode of growth in transition economies and agriculture, although this type of growth is generally considered costly and debt-generating (Walther, 2014). Additionally, acquisitions often fail due to poor integration of target firms (Capron and Mitchell, 1997; Karim and Capron, 2016; Steigenberger, 2017; Weber and Camerer, 2003). Within such a setting, the long-term viability and sustainability of firms that grow primarily via acquisitions is questionable (Ramezani et al., 2002). Nevertheless, some of the agroholdings have developed this way for more than 15 years.

In this context, previous empirical studies of agroholdings failed to give a detailed account of an ongoing acquisitive activity of agroholdings that can provide an explanation of their efficiency deficits. Therefore, it is important to determine: (1) the outcomes of acquisitions by agroholdings; (2) the process by which agroholdings integrate acquired farms; and (3) the factors explaining the differences in achieving profitable growth among the farms acquired by agroholdings. This study aims to fill these gaps by comparing how agroholding-affiliated farms develop after an acquisition vis-à-vis their structurally similar counterparts, i.e. non-agroholding farms. In particular, we explore the post-acquisition integration instruments that agroholdings apply to farms and scrutinize the effects of acquisitions on the organic growth and performance of acquired farms. Furthermore, we assess how agroholding-affiliated farms develop based on their strategic post-acquisition growth orientations to understand which farms are able to grow profitably. We fulfill these objectives by applying several estimation techniques, including regression analysis, factor analysis, nearest neighbor matching and categorization techniques, to farm-level data of approximately 8,700 corporate farms collected from 2005-2016 in Ukraine.

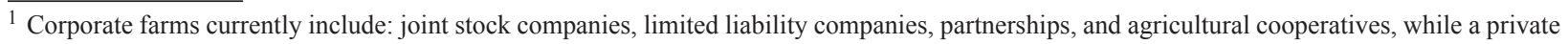
farm is a synonym of a peasant farm (Lerman et al., 2007).
} 
The paper is structured as follows. First, we provide insights on our empirical context by describing the development and role of agroholdings in Ukraine. Second, we elaborate theoretically on the issue of firm growth and the process of post-acquisition integration of firms. Third, we provide information about the dataset and methods used. Fourth, we present our results. Finally, we discuss our findings and conclude.

\section{Development of agroholdings in Ukraine}

The severe economic crisis at the end of the 1990s forced investors in transition economies to search for diversification opportunities. In Ukraine, devaluation of the national currency led to the restriction of food imports and enhanced competitiveness and profitability of local agriculture (Wandel, 2011). As a result, agriculture has become an attractive niche for outside investors who recognized other benefits of the Ukrainian farming sector, such as the fertile soils, favorable weather conditions, relatively cheap land and labor, and ability to exploit economies of scale and scope (Gagalyuk, 2017). Subsequent inflows of external capital resulted in the emergence and evolution of large-scale vertically and/or horizontally integrated business groups, which are often referred to as agroholdings (Matyukha et al., 2015).

The institutional environment in Ukraine has been highly conducive to the development of agroholdings. Particularly, agricultural policies that aim to facilitate farm incomes, i.e. preferential hectare-based taxes and coupled subsidies, were among the main drivers of farm consolidation. Even today, some agroholdings are among the main recipients of public support (cf. Gagalyuk, 2017: 262; Lapa et al., 2015).

Another factor driving agroholding proliferation is the more favorable access to external sources of capital compared to other types of farms (Gagalyuk, 2017). Agroholdings are able to raise capital through lowinterest loans from local and international commercial banks, issuance of bonds and listings on international stock markets and private equity funds (Balmann et al., 2013; Gagalyuk and Valentinov, 2019).

Additionally, Ukraine's land reform process can be considered a driver of large-scale agriculture. During the reform process, approximately 7 million rural inhabitants became owners of physical land plots and were able to either establish their own farms or earn income from renting out their shares to corporate farms. At the same time, the moratorium on buying and selling farmland was introduced in 2001 and has been in effect until present. Along with prevailing smallholder land ownership, the moratorium on land sales promotes the development of agroholdings in several ways. First, it restricts the growth of land rent prices and promotes the accumulation of vast amounts of land, although only via lease agreements. Second, the absence of formal land lease duration limitations (up to 2015) allowed for very long-term leases that led to a de facto absorption of land in corporate equity (cf. Gagalyuk et al., 2018: 683).

The abovementioned factors allowed agroholdings to grow in terms of operation area and invest in modern technologies and infrastructure, which enabled yield increases in both crop and livestock production (Deininger and Byerlee, 2012). During the major period of land accumulation (2007-2013), agroholdings increased their area 3.5 times to more than 6 million hectares, or $27 \%$ of the total farmland operated by corporate farms (Figure 1). Today, agroholdings account for $29 \%$ of the farmland area, $59 \%$ of crop production and $44 \%$ of animal production among corporate farms in Ukraine (or 20\% of crop production and 29\% of animal production of all types of agricultural producers, including all types of farms and household producers) (UCAB, 2019). A recent slowdown of agroholding expansion has been mainly attributable to the unrest in the eastern part of the country and Russian annexation of Crimea (ibid).

In Ukraine, land can be accumulated via leases from individual landowners, i.e. rural inhabitants. However, this approach is associated with high transaction costs related to searching for land lessors, the conclusion and management of individual land lease contracts, and the consolidation of dispersed and small land plots (the average size of a plot is 4.2 hectares per landowner, while the average size of a farm is approximately 2,000 hectares in Ukraine). Therefore, agroholdings engage actively in acquisitions, i.e. purchase of controlling stakes in and land lease rights from standalone corporate farms that managed to consolidate at an earlier 


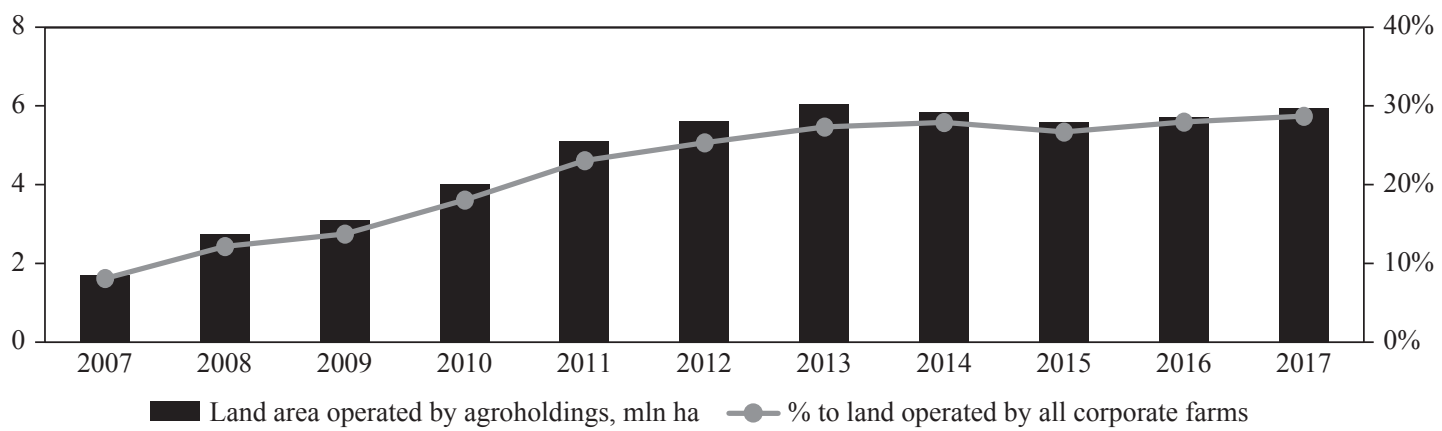

Figure 1. Land operated by agroholdings (UCAB, 2019).

stage of the land reform (Balmann et al., 2013). Although agroholding expansion rates are much lower now than in the early 2010s, agricultural merger and acquisition (M\&A) deals in Ukraine play a significant role in the local market of corporate takeovers. According to the study by KPMG (2019), 5 out of the 10 largest M\&A deals in 2018 involved agriculture. Moreover, agriculture holds a leading position among the branches of the Ukrainian economy by the number and value of M\&A deals (ibid). In this context, it is surprising that few studies on firm/farm growth have focused on the processes and outcomes of the acquisitive growth of agroholdings.

\section{Literature overview on merger and acquisition growth of firms and farms}

\subsection{Firm growth through mergers and acquisitions: pre-acquisition conditions, post-acquisition integration and timing of acquisitions}

The strategic management literature outlines two 'standard' modes of firm growth (Kim et al., 2011). The first mode is so-called organic growth, which involves growth via a firm's own resources through internal expansion or an increase in demand for the firm's services and products (Kim et al., 2011; Penrose, 1995). The second mode of growth is referred to as mergers and acquisitions $(M \& A)^{2}$, which represents expansion through the purchase (acquisition) of or unification (merger) with another firm (Palmer et al., 1993; Penrose, 1995).

A substantial part of existing M\&A research deals with the outcomes of M\&A for the firms involved in this mode of growth. Generally, empirical research on the effects of M\&A on firm development produces mixed results. On the one hand, M\&A serve as an instrument to access additional bundles of resources (or productive sets), improve efficiency and productivity, increase market power, and achieve other positive effects arising from the exploitation of synergies among the involved firms (Capron et al., 1998; Nelson and Winter, 1982; Penrose, 1995; Vermeulen and Barkema, 2001). On the other hand, M\&A may lead to shrinkage of financial performance and R\&D intensity, thus impelling firms to divest resources and businesses (Hitt et al., 1991).

Surprisingly, few studies have explicitly investigated the impact of M\&A on a firm's organic growth (McKelvie and Wiklund, 2010). Instead, the major focus is on intermediary outcomes, such as firm productivity, financial and innovation performance. Analyses of these effects are not unimportant, but they provide little insights into how firms shape their ability to sustain post-acquisition organic growth, which is widely considered to be characteristic of a self-sufficient firm and therefore represents a 'healthier' mode of growth (Davidsson et al., 2009; Penrose, 1995).

\footnotetext{
${ }^{2}$ Despite the difference between the terms 'merger' and 'acquisition', researchers frequently use them interchangeably (Penrose, 1995; Steigenberger, 2017). The word 'merger' is often used to relax the resistance of a target or society, although mergers constitute only about $3 \%$ of the total number of M\&A deals worldwide (Teerikangas and Very, 2006).
} 
One reason behind the variation in the post-acquisition development of firms is that the acquisition outcomes may be a function of an interplay among several factors, including the pre-acquisition conditions of firms, processes of post-acquisition firm integration, and timing of acquisitions (Capron, 1999; Capron et al., 1998; Haspeslagh and Jemison, 1991; Shrivastava, 1986; Steigenberger, 2017). With regard to the pre-acquisition conditions of firms, the literature suggests that acquisitions may often be driven by the so-called inefficiency rationale (Balsvik and Haller, 2010), whereby acquirers choose to overtake low-performing targets, which are less costly and more likely to offer greater opportunities for efficiency improvements (Haleblian et al., 2009; Nguyen and Ollinger, 2006 ; Ostapchuk et al., in press). Alternatively, the acquiring firms may select highly performing targets that have related efficiencies and therefore confer opportunities to achieve synergetic effects and further efficiency enhancements (Balsvik and Haller, 2010).

From the resource-based theory perspective, post-acquisition integration (PAI) of acquired firms is 'the process that unfolds in the aftermath of the deal closure to reconfigure merging firms by redeploying, adding, or divesting resources, lines of products or entire businesses, in order to achieve the expected combination benefits' (Bodner and Capron, 2018: 2). PAI reveals the extent to which an acquirer changes a target, and a significant portion of success in acquisitions depends on proper PAI (Graebner et al., 2017). At the firm level, PAI involves resource allocation to a preferred production line within an acquired firm; at the intracorporate level, it involves resource redeployment between an acquirer and a target; and at the external level, it includes the purchase of resources from outside of the organization and/or divestment of resources or parts of a business to third-party organizations (Bodner and Capron, 2018; Capron, 1999; Capron and Mitchell, 1997; Capron et al., 1998, 2001; Shrivastava, 1986; Steigenberger, 2017).

Finally, the timing of acquisitions refers to the phase of market/economy development. Harford (2005) suggests that acquisitions tend to cluster in time, thus forming acquisition waves, especially in times when the conditions of strategic factor (i.e. capital) markets are favorable. Competition for a target, desire to catch up with market rivals, and need to demonstrate growth (e.g. to satisfy shareholders) drive the formation of acquisition waves and pose a risk of target overvaluation (Rhodes-Kropf and Viswanathan, 2004). Therefore, an acquiring firm is likely to have fewer resources for proper target integration and growth stimulation during an acquisition wave than during periods outside of the wave.

\subsection{Mergers and acquisitions in agriculture: growth and post-acquisition integration of farms}

In contrast to the strategic management literature, agricultural economics and agribusiness studies have largely ignored the topic of M\&A. One reason for the scarcity of research on agricultural M\&A is that M\&A processes in primary agriculture globally were infrequent until the emergence of agroholdings in the early 2000s. As a result, the major focus of farm growth research has been on the organic growth mode and its drivers. The implications of economies of size, total and partial factor productivities, transaction costs, managerial capabilities, policy changes and many other factors for organic growth have been widely addressed in various country contexts (Buduru and Brem, 2007; Byerlee and Deininger, 2013; Deininger et al., 2018; Francksen et al., 2012; Hallam, 1991; Matyukha et al., 2015; Piet et al., 2012; Schroeter et al., 2006). A number of studies have investigated the effects of farm size on growth by testing 'Gibrat's Law of Proportionate Effects', which proposes that proportionate changes in size are independent of the current size and past history of a farm (Shapiro et al., 1987; Rizov and Mathijs, 2003; Weiss, 1999). However, none of these studies have found support for this proposition.

A few notable exceptions of M\&A studies published in agricultural economics journals represent quantitative analyses of the M\&A implications in the food processing industry (Ebneth and Theuvsen, 2007; Filippaios and Rama, 2011; Herger et al., 2008; Klimek and Hansen, 2017; Muehlfeld et al., 2011; Nguyen and Ollinger, 2009) and case studies of M\&A in the primary agriculture sector (Chaddad and Boland, 2009; Lamprinakis and Fulton, 2011; Tao and Xie, 2015; Wolfe et al., 2011). However, quantitative analyses of acquisitions and their outcomes in primary agriculture are practically absent. Nevertheless, we believe that some insights into this topic can be gained from up-to-date research on agroholdings, which is a farming organization wherein acquisitions are the dominant mode of growth (Mamonova, 2015; Walther, 2014). 
In particular, studies on agroholdings demonstrate that the variation in the acquisition outcomes may result from the initial conditions for acquisitions and differing approaches to the PAI of acquired farms by agroholdings. Within this research stream, most existing studies involve performance comparisons between agroholding-affiliated and standalone (non-agroholding) farms. For instance, early studies by Hockmann et al. (2005) and Hockmann et al. (2007) showed that agroholding-affiliated farms in Russia lagged behind other organizational forms in terms of economic efficiency. Subsequent studies by Hahlbrock and Hockmann $(2011,2012)$ found that in Russia, agroholding-affiliated farms were able to outperform standalone farms in terms of total factor productivity due to the technological superiority of agroholdings. Along similar lines, Epstein et al. (2013) reported that agroholding-affiliated farms in Russia demonstrated higher total factor productivity than non-agroholding farms due to significant investments in modern technology. Similarly, Balmann et al. (2013) found that agroholding-affiliated farms in Ukraine had higher production input use intensities that enabled higher and faster growing yields than standalone farms. However, on average, agroholding farms were not more profitable than standalone farms. Matyukha et al. (2015) found only minor differences between agroholding-affiliated farms and their standalone counterparts in Russia. Any advantages of affiliated farms were associated with the agroholdings' abilities to link individual production units (i.e. individual affiliated farms), position themselves in local and regional markets and obtain benefits associated with political lobbying activities. In contrast, Lapa et al. (2015) reported that despite the ability to link numerous production units, Ukrainian agroholdings faced high transaction costs associated with the need to coordinate these units. Some agroholdings also focused primarily on land consolidation and were less concerned with efficiency improvements.

However, the above comparative analyses of agroholdings vis-a-vis standalone farms do not single out the growth effects of acquisitions themselves and provide limited insights on the reasons for performance differences caused by farm acquisitions, i.e. farm status change from standalone to agroholding-affiliated, and instruments applied by agroholdings to integrate acquired farms after the acquisition event takes place. Moreover, these analyses do not provide empirical explanations of the variations in farm restructuring, performance and growth among the agroholding-affiliated farms, i.e. within the group of acquired farms. Determining these factors is crucial for an in-depth understanding of the economic side of agroholding expansion. Therefore, we refer to some findings of the above literature overview to provide a general hypothesis on the potential outcomes of acquisitions for farm restructuring, performance and growth.

In particular, we expect that acquisitions will have significant positive effects on acquired farms' productivity and size growth and a less positive effect on profitability. Favorable access to financing allows agroholdings to invest in more expensive and higher-quality production inputs than standalone farms. Investment in modern technology results in higher productivity and sales as well as larger production costs. Agroholdings' ability to consolidate separate production units under one 'umbrella' helps to achieve economies of scale but is not a sufficient factor for outperforming standalone farms in terms of profitability in the short run due to the ongoing acquisition and post-acquisition processes in agroholdings.

Although the effects of acquisitions on farm performance and growth are positive, we expect them to vary systematically due to differing pre-acquisition characteristics of the acquired farms and (the resulting) PAI strategies adopted by agroholdings. Various PAI instruments may have different effects and payoff periods. For example, agroholding can improve the efficiency of resource use by reallocating resources within an acquired farm and achieve positive effects for both performance and growth in the short run. The divestment of excess, outdated or noncore resources can be positive for scale efficiencies and profits but does not necessarily and immediately lead to organic growth (Capron et al., 2001). Investment in fixed assets can improve productivity and growth at the expense of short-term profits. In turn, investment in variable inputs can bring about short-term positive effects resulting from the use of more productive and balanced seed varieties, fertilizers and crop protection products. These effects can be subsequently enhanced over time, such as through improvements in soil fertility (FiBL, 2016; Havlin and Heiniger, 2020). Therefore, we generally hypothesize that the achievement of positive acquisition effects will show temporal variability. 
Moreover, the assumption that agroholdings acquire farms with different features implies the certain farm characteristics are induced by factors unrelated to the farm type, such as access to resources (land and financing), public policies, regional proximity to agroholdings' operation areas and export infrastructure. Specific farm endowments and inefficiencies will require different PAI strategies and adjustment costs, which result in different effects of acquisitions. In addition, low-efficiency production is a general characteristic of agriculture in Ukraine (Balmann et al., 2013); therefore, agroholdings' acquisitions may often be motivated by the 'inefficiency rationale' (Balsvik and Haller, 2010). Accordingly, we expect that pre-acquisition targets exhibiting less efficiency and less growth will demonstrate higher growth and performance rates (at least in the short run) after an acquisition. We further present the data and empirical strategy employed to verify these hypotheses.

\section{Data}

We use a longitudinal dataset provided by the State Statistics Service of Ukraine (SSSU), and it consists of approximately 105,000 observations for the years 2005-2016 with detailed farm-level accounting data. Additionally, we use information on farms' affiliation with agroholdings. The original data on farm agroholding affiliations in 2011-2016 were obtained from the Association 'Ukrainian Agribusiness Club' (UCAB). ${ }^{3}$ We then cross-checked and expanded this dataset with the information from the SPARK Interfax (Interfax, 2018) and YouControl (YouControl, 2019) databases, which provide information from official public registers on enterprise ownership and thus can be used to trace farm affiliations with agroholdings.

An important task in the course of data preparation was to define the acquired farms in our dataset. A farm was considered to be acquired by an agroholding if it was operating before the acquisition and the ownership rights to the farm were transferred to an agroholding mother company or an agroholding-affiliated farm. We excluded from our analysis a number of farms whose ownership was unclear due to ambiguous information provided in the UCAB database and official registers. ${ }^{4}$ Additionally, we excluded farms that were newly established by agroholdings. ${ }^{5}$ Overall, the share of agroholding-affiliated farms ranged from $2 \%$ (2005) to $8 \%$ (2016) of the total number of observations in our sample (Table 1).

Within the timeframe of our dataset, i.e. from 2005 to 2016, we focused only on acquisitions that took place from 2008 to 2015 for two reasons: first, we wanted to be able to identify whether a farm was acquired or newly established by an existing agroholding; and second, we aimed to ensure efficient matching on the farms' pre-acquisition characteristics (see next section for more information on the methodology used).

Table 1 provides year-by-year frequencies of new agroholding affiliations in our dataset. In total, we identified 1,338 new agroholding affiliates in 2005-2016, of which 753 farms (or 56\%) were acquired, i.e. there was a transition of farm ownership.

\section{Methods and model specification}

Our empirical strategy encompasses two stages. First, to understand how acquired farms are integrated and the outcomes associated with acquisitions, we apply the direct nearest neighbor matching (NNM) technique, which allows us to compare acquired (treated) farms with structurally similar non-acquired (control) farms and estimate the average treatment effects on the treated (ATET) (Abadie et al., 2004; Abadie and Imbens, 2006). Considering the scarcity of the research on M\&A using production-level data that could be used

\footnotetext{
${ }^{3} \mathrm{UCAB}$ is the association of Ukrainian agroholdings, input suppliers, and service providers for agriculture. UCAB continuously updates information on agroholding affiliation using reports of the Antimonopoly Committee of Ukraine, data from open sources as well as own surveys of agricultural enterprises in Ukraine.

${ }^{4}$ Petrick et al. (2012) faced the same issue in their study of Kazakh agroholdings.

5 The main reason for this exclusion is the absence of information on the source of resources of these farms. Therefore, we cannot confirm the transfer of resources after an acquisition of a particular farm. Moreover, the distribution of an acquired farm's resources among other agroholdingaffiliated farms or a merger of resources from several acquired farms under one legal entity significantly complicates or even makes it impossible to identify the origin of the resources.
} 
Table 1. Frequencies of farm acquisitions by year, 2005-2016.

\begin{tabular}{|c|c|c|c|c|c|c|}
\hline Year & $\begin{array}{l}\text { Total no. } \\
\text { of farms } 1\end{array}$ & $\begin{array}{l}\text { No. of agroholding } \\
\text { subsidiaries }\end{array}$ & $\begin{array}{l}\text { Share of agro- } \\
\text { holding subsidiaries }\end{array}$ & $\begin{array}{l}\text { No. of new agro- } \\
\text { holding affiliates }\end{array}$ & $\begin{array}{l}\text { No. of identified } \\
\text { acquisitions }\end{array}$ & $\begin{array}{l}\text { Share of } \\
\text { acquisitions }\end{array}$ \\
\hline 2005 & 8,520 & 164 & $1.9 \%$ & 21 & 0 & $0 \%$ \\
\hline 2006 & 7,611 & 192 & $2.5 \%$ & 31 & 19 & $61 \%$ \\
\hline 2007 & 8,287 & 184 & $2.2 \%$ & 55 & 32 & $58 \%$ \\
\hline 2008 & 9,278 & 389 & $4.2 \%$ & 87 & 45 & $52 \%$ \\
\hline 2009 & 9,249 & 441 & $4.8 \%$ & 105 & 82 & $78 \%$ \\
\hline 2010 & 9,180 & 560 & $6.1 \%$ & 154 & 102 & $66 \%$ \\
\hline 2011 & 9,538 & 680 & $7.1 \%$ & 270 & 164 & $61 \%$ \\
\hline 2012 & 9,160 & 747 & $8.2 \%$ & 241 & 106 & $44 \%$ \\
\hline 2013 & 9,105 & 747 & $8.2 \%$ & 103 & 60 & $58 \%$ \\
\hline 2014 & 8,561 & 695 & $8.1 \%$ & 14 & 7 & $50 \%$ \\
\hline 2015 & 8,501 & 671 & $7.9 \%$ & 56 & 31 & $55 \%$ \\
\hline 2016 & 8,303 & 668 & $8.0 \%$ & 201 & $105^{2}$ & $52 \%$ \\
\hline Total & 105,293 & 6,138 & $5.8 \%$ & 1,338 & 753 & $56 \%$ \\
\hline
\end{tabular}

to select relevant covariates for matching and determine the structure of the outcome variables, we run two complementary analyses. We apply (1) multiple logistic regressions to identify factors that affect the agroholding's decision to acquire a particular farm. These factors are used during matching to ensure that high-quality matches are obtained by satisfying the unconfoundedness assumption. We also apply a (2) factor analysis with the aim of assigning available variables to the particular PAI instruments. In the second part, we categorize acquired farms based on the post-acquisition growth of farm profits and size and examine the pre-acquisition characteristics of the farms in given categories. We aim to identify agroholdings' postacquisition growth strategies, particularly to reveal the PAI instruments and subsidiary farm types that deliver profitable post-acquisition growth. The latter is especially important in light of the common belief that strategies other than profitable growth may destroy firm value (Davidsson et al., 2009; Kogut and Zander, 1992). We adapt the method used by Davidsson et al. (2009) by categorizing the acquired farms using a two-dimensional profit-size-growth matrix. Our approach is unique in categorizing individual ATET profit and size-growth predictions.

\subsection{Nearest neighbor matching model and variable specification}

A number of recent studies on firm post-acquisition performance deploy matching methods (Arndt and Mattes, 2010; Renneboog et al., 2017; Stiebale and Trax, 2011). 'Matching' can be generally defined as any method that aims to equate the distribution of covariates in the treated and control groups so that a comparison of the groups' outcomes is not confounded by the measured and balanced covariates (Stuart, 2010). Using suitable covariates, the matching methods are characterized by high efficiency and reliability of the treatment effects (impacts) because several key sources of bias are avoided (i.e. selection, simultaneity and misspecification biases) (Dehejia and Wahba, 1999, 2002; Glazerman et al., 2003). However, the application of parametric methods, such as difference-in-difference (DiD), to matched samples of panel data may also represent a possible alternative approach. An attractive property of $\mathrm{DiD}$ is that it relaxes the assumption of selection only on observed characteristics (Khandker et al., 2010). However, given our consideration of different farm acquisition stages in Ukrainian agriculture, the notion that the selection bias stemming from unobserved characteristics is time-invariant seems implausible. Another disadvantage of the DiD approach is its parametric specification, which imposes constraints on the functional form of the treatment model as well as assumptions about the distribution of the error term (Khandker et al., 2010). Moreover, to use the 
DiD approach, the parallel pre-treatment trend assumption must be satisfied while it ignores the differences in pre-treatment levels between treated and control groups. Therefore, this approach addresses selection bias less efficiently. Researchers combine DiD with matching to address this issue, although recent evidence suggests that matching may reduce the bias but not fully eliminate it (Lindner and McConnell, 2018). The objective of our study is to explore the acquisition effect on several outcome variables and subgroups of observations; thus, displaying all covariates for the parameters would introduce certain challenges when presenting the results. Thus, a matching method represents a more suitable approach for our study.

Several methods are available for performing matching. Given the structure of our data, which includes many more control farms than treated farms (Table 1), and the interest in estimating ATET, we follow Stuart's (2010) recommendation to apply direct $(k: 1)$ nearest neighbor matching without replacement instead of a propensity score-based matching approach. ${ }^{6}$ Nearest neighbor matching represents a simple and high-performance approach (Stuart, 2010: 19). The direct NNM method matches each observation directly by pairing them using a weighted function of selected covariates based on the proximity of values (closest match). Direct NNM requires fewer functional form assumptions and thus suffers less from potential misspecification than parametric regression-based or propensity score-based matching approaches (Imbens and Wooldridge, 2009). ${ }^{7}$

However, this method requires a large number of observations and structural covariates with sufficient variance in both the treatment and control groups used for observation pairing. Our dataset satisfies both requirements (Tables S2 and S3). Additionally, we tested the performance of our NNM procedures by assessing the covariate balance via standardized mean differences (SMDs) and using the overlap test. The results of these tests show the accuracy of NNM matching (Tables S6-S9).

The treated farms in our case are those acquired by agroholdings, while the control group includes nonacquired non-agroholding farms. The model identifies structurally similar farms from both groups based on the set of pre-acquisition characteristics and estimates the average differences in outcome variables between these farms in the post-acquisition years ranging from $\mathrm{t}+1$ (one year after an acquisition) to $\mathrm{t}+7$ (seven years after an acquisition). Analysis of the PAI instruments and outcomes year-by-year allows us to address the criticism in firm growth research on the use of static models (Davidsson et al., 2009). Our models are calculated for the entire period, i.e. for the acquisitions made from 2008-2015, as well as for the different acquisition stages, i.e. pre-wave period (2008-2009), within-wave period (2010-2012), and post-wave period (2013-2015), to control for the effects of acquisition target overvaluation (Rhodes-Kropf and Viswanathan, 2004). Additionally, we capture the differences among farms with crop and animal production specializations.

\section{- Covariates}

Covariates in NNM are used to ensure quality matches in terms of pre-treatment characteristics of observations to satisfy the strong ignorability assumption (Rosenbaum and Rubin, 1983). Previous research suggests that the process of acquisition target selection is not random (Ostapchuk et al., 2021; Salis, 2008). Therefore, the PAI model should contain structural variables (covariates) that affect the probability of being treated. The regressions presented in Table S4 identified the following statistically significant predictors of farm acquisitions: farm production value, land area, specialization, input use intensities (material costs, capital, services and labor), overheads, land rent, productivity (crop production per hectare and milk production per cow), legal form and operation region. We use these variables as covariates for NNM.

\footnotetext{
${ }^{6}$ In the case of matching without replacement, the controls are used as matches only for one treated object; thus, the controls remain independent. The $k: 1$ ratio matching is based on the ratio of the control to treated observations. Stuart (2010) argues that a 1:1 matching involves the lowest bias but increases the variance and thus reduces the explanatory power of the model. We follow the general recommendation of four controls to one treated object (Abadie and Imbens, 2002, 2011; Abadie et al., 2004; Klepac and Hampel, 2017).

${ }^{7}$ In the case of propensity score matching (weighting), the weights come directly from the estimated propensity score model and, therefore, are more sensitive to its correct specification (Greifer, 2020).
} 


\section{- Outcome (dependent) variables}

Our NNM models account for two groups of dependent variables: (1) PAI instruments represented by changes in cost structures of acquired farms and thus reflecting the intensity of acquired farms' integration into agroholdings; and (2) organic growth and performance of farms after an acquisition.

Despite a large number of studies on the PAI of firms, the operationalization of PAI instruments in the context of agriculture is a challenging task due to the scarcity of research on this issue. Therefore, we assign specific variables to particular PAI instruments based on the previous literature on firm PAI as well as factor analyses applied to our data and reported in Table S5. The available data can be used to operationalize PAI within three major groups of post-acquisition resource integration instruments: (1) resource allocation (recombination), which represents the allocation of resources to a specific production line within an acquired farm; (2) investment/divestment, which indicates the extent to which agroholding changes the resource base of an acquired farm using sources external to the agroholding; and (3) redeployment of resources between an acquirer and a target within the agroholding structure. The results of our factor analysis also suggest differentiating between investment/divestment activities based on the type of resources. Namely, we distinguish between investment in or divestment of the variable inputs, fixed assets, labor and services.

We also compare acquired and non-acquired farms along several performance measures. These measures include changes in profits, partial factor productivities and crop and animal productivity (yields).

Despite the ongoing debate in the literature on the operationalization of firm organic growth, there is broad consensus that sales volume is an appropriate measure of firm size (Coad, 2009; Delmar, 1997; Shepherd and Wiklund, 2009; Sumner, 2014). ${ }^{8}$ Therefore, we use the absolute change in sales volume to measure the organic growth rate of a farm.

The operationalization, grouping and description of the variables are presented in Table S1, while descriptive statistics are provided in Tables S2 and S3.

\subsection{Post-acquisition profit/growth categorization}

To identify the characteristics of profitably growing farms, we apply a post-acquisition farm categorization based on Davidsson et al. (2009), who grouped a sample of firms into five categories based on firms belonging to a particular profit and growth quartile and accounted for the firms that exited from the sample. Furthermore, they estimated the rates of firm transition between the groups during a 3-year period. We extend this approach in several ways. First, we adapt it to the context of PAI by using post-acquisition profit and size growth, i.e. our ATET results, for the grouping of farms. Second, similar to the original method, we estimate the profit and size growth quartiles that the acquired farms belong to, although we do this only for the sample of acquired farms. Third, we use an additional category compared to Davidsson et al. (2009) to account for extensively growing farms in the post-acquisition period. Additionally, a category of farms includes those that dropped out from our sample due to liquidation shortly after an acquisition (Figure 2). In most cases, however, these farms did not exit the farming activity physically since the agroholdings merged them with other farms within agroholdings' structures. Thus, these farms were liquidated only as a legal entity and we can trace their development before and after an acquisition.

The acquisitions with low profit growth (first and second quartiles) and low size growth (first and second quartiles) are considered to have a 'low effect'. Those with high profit growth (third and fourth quartiles) and low size growth are 'profit growth-oriented acquisitions', while those with low-profit and high-size growth are 'size growth-oriented acquisitions'. The farms that manage to show high growth in terms of

\footnotetext{
${ }^{8}$ Farms may have different sales strategies: some prefer immediate postharvest sales while others keep produced goods longer based on an expectation of higher prices. As a result, annual sales may not represent the full size of a farm. Therefore, we estimate production values in fixed prices for the year 2005, which corresponds to deflated sales for a marketing year. We use the terms 'production value' and 'sales' interchangeably.
} 


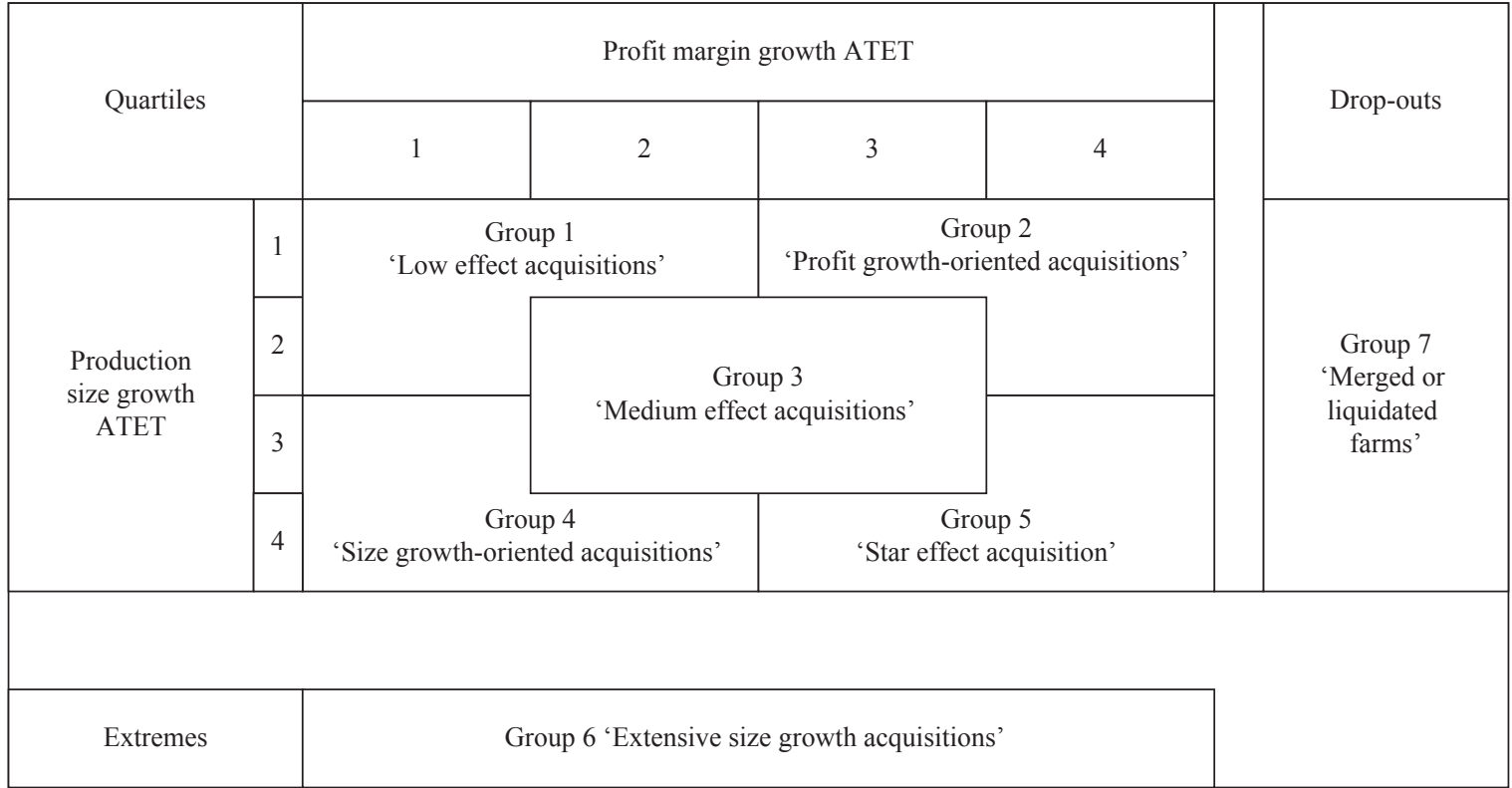

Figure 2. Categorization schema of farms based on post-acquisition profit and size growth (Davidsson et al., 2009). ATET = average treatment effects on the treated.

both profit and size growth are called 'star effect acquisitions'. There are also groups of farms with medium outcomes (i.e. 'medium effect acquisitions') and 'merged or liquidated farms'. We additionally identify the farms that show substantial growth in land area for operations after an acquisition (i.e. 'extensive size growth acquisitions'). ${ }^{9}$ It is important to distinguish between the effects stemming from extensification and the effects caused by the improvement of acquired farms' operations.

The variables for the categorization (except the pre-acquisition characteristics) were constructed as the ratio of individually (farm-level) predicted ATETs to the absolute value of the respective variable in period $\mathrm{t}-1$, i.e. the year preceding an acquisition. This process enables us to simultaneously interpret the obtained values for both the 'within' and 'between' modes of farm changes. The 'within' mode concerns the growth or decline of a particular indicator on an acquired farm. If the value of an indicator is greater than 1, then it denotes growth; and if it is lower than one, then it denotes decline. The 'between' mode indicates whether the change in a particular indicator on an acquired farm is positive or negative, i.e. whether an indicator is greater or lower than zero, respectively, relative to the change in a respective indicator of a structurally similar non-acquired farms. For relative variables, such as profit margin, the absolute change of an indicator through the period from t-1 to a specific year was used. These variables are labeled with an asterisk $(*)$ in the results tables.

Furthermore, we estimate the median values ${ }^{10}$ of the farm pre-acquisition characteristics, the rates of PAI instruments use, and the implications for growth and performance for each farm group in different postacquisition time periods (i.e. $\mathrm{t}+1, \mathrm{t}+3$, and $\mathrm{t}+5$ ). The statistical significance of the differences between the groups was tested using the Kruskal-Wallis equality-of-populations rank test (Kruskal and Wallis, 1952). Finally, we analyze the extent to which farms transition between the groups in different time periods. The estimations were carried out using Stata 16.0 statistical software (StataCorp LLC, College Station, TX, USA).

\footnotetext{
${ }_{9}^{9}$ We consider a farm as extensively growing if its operation area increased after an acquisition by the factor of 2.5. This point was identified using histogram analysis.

${ }^{10}$ Median is preferred over mean due to its ability to minimize the effect of potential outliers.
} 


\section{Results}

\subsection{Post-acquisition integration in Ukrainian agroholdings using nearest neighbor matching}

\section{- Resource allocation}

Our findings suggest that the acquired farms allocate resources toward crop production (as opposed to animal production) more actively than the non-acquired farms (Table S10). Although the majority of the acquired farms were initially crop-specialized, the share of crop production among the total production increases on average by 4 percentage points (p.p.) in $t+1$ and by 2 p.p. more in the later periods. Additionally, the changes in the structure of production were discernible based on the higher growth rate of the share of cash crops and higher growth rate of the share of milk production in animal production. This finding holds for the farms acquired in the pre-acquisition-wave period. There were also noticeable positive changes with regard to the ratio of harvested arable land to total arable land. Newly acquired farms operate 9 to $29 \%$ more of their available arable land in $\mathrm{t}+1$, indicating a return of earlier unused farmland into operation.

\section{- Investment/divestment}

We distinguish between investment in or divestment of variable inputs, fixed assets, labor and services. Variable inputs show statistically significant long-lasting growth in crop production only after pre-wave acquisitions. In turn, the estimation based on the whole sample indicates a higher cost of fertilizers only during $\mathrm{t}+1$ and higher costs of seeds only during $\mathrm{t}+2$ and $\mathrm{t}+3$. Post-acquisition development of variable inputs in animal production (operationalized by material costs and feedstuff costs) shows mainly statistically insignificant changes.

We find evidence of different PAI strategies regarding fixed assets in crop production depending on the timing of acquisitions. Particularly, the farms acquired in the pre-wave period experience higher investments in fixed assets during early post-acquisition years (up to $t+2$ ). The acquisitions made during the acquisition wave demonstrate an increasing divestment of fixed assets, while the difference between acquired and nonacquired farms is not statistically significant in the post-wave period. The land area of the acquired farms tends to expand shortly after the acquisitions made before and after the acquisition wave, while the farms acquired during the wave expand their land area first after three years. Additionally, we observe higher use of labor by the farms acquired before the wave. In contrast, the farms acquired during the wave tend to divest labor. The difference between acquired and non-acquired farms in the post-wave period is insignificant. The results regarding investment in or divestment of fixed assets and labor in animal production are inconclusive.

The acquired farms demonstrate statistically significant growth in the use of third-party services. In particular, we observe a higher intensity of third-party service use in crop production (Figure 3A). The difference between acquired and non-acquired farms becomes significant already in $\mathrm{t}+1$ and remains throughout the period of analysis. The differences between acquired and non-acquired farms in the use of such services in animal production are lower than in crop production and statistically significant up to $t+4$. In view of the divestment of fixed assets, especially by farms acquired during the acquisition wave, agroholdings may prefer to outsource some costly services, e.g. harvesting or fodder storage, or substitute costly investments in fixed assets with services, such as leasing machinery and equipment at the farm level.

Additionally, we found significantly higher growth of overhead costs (sales, general and administrative (SG\&A) costs) on acquired farms in crop production, while the difference between acquired and nonacquired farms in animal production was statistically insignificant. Higher SG\&A costs on acquired farms in crop production appear to be statistically significant mainly during the year after an acquisition and are of a long-lasting nature (Figure 3B). The initial growth and subsequent decline of this indicator points to the existence of adjustment costs related to the adaptation of farm infrastructure and management systems in the process of integration. 

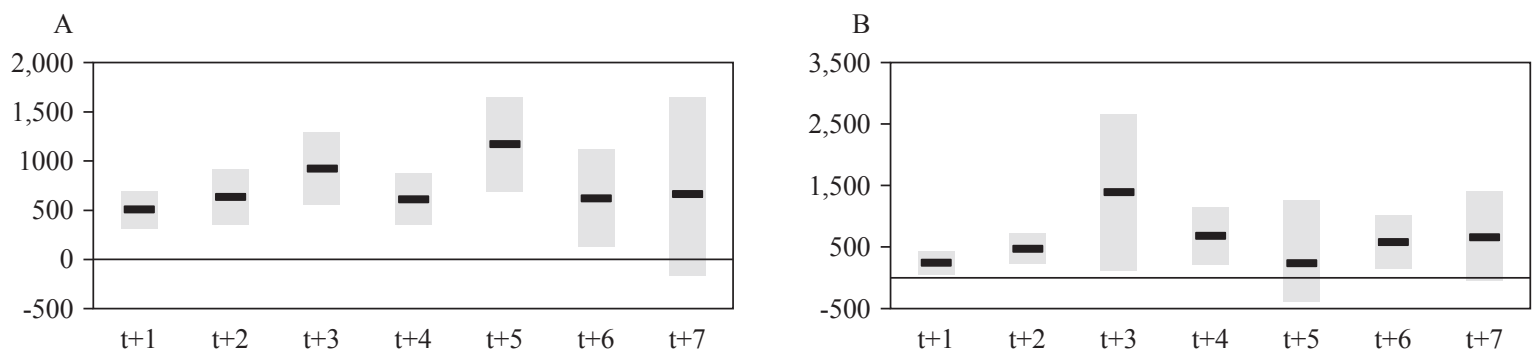

Figure 3. Post-acquisition development of third-party services (A) and sales, general and administrative costs (B) in crop production, $1000 \mathrm{UAH}$. Black dashes represent average treatment effects on the treated and grey bars represent $95 \%$ confidence intervals. Estimations were carried out for the whole sample, i.e. acquisitions made during 2008-2015. The official exchange rate as of the end of 2005 was USD $1=$ UAH 5.05.

\section{- Resource redeployment}

We found no statistically significant differences between acquired and non-acquired farms in worker salaries in either crop or animal production. However, agroholdings are likely to motivate landowners by increasing land rent payments the next year after an acquisition. Land rent payments increase on average by UAH 2025 per hectare (in 2005 deflated prices), which corresponds to $16-24 \%$ of the weighted average land rent payment in the pre-wave period or 11-19\% during the acquisition wave. Differences in land rent payments between acquired and non-acquired farms develop fluctuations as well. The decreasing difference in the middle of the post-acquisition period suggests that the non-acquired farms first tend to adjust and pay the same high rents as the acquired farms, while the difference tends to increase again in later post-acquisition periods. This finding suggests that agroholdings may take the role of price leaders in land rental markets (Graubner et al., 2021), although they cannot afford to pay the highest possible land rents during the entire post-acquisition period due to the high costs of acquisitions themselves.

Generally, the results show that acquired farms undergo a profound PAI process. However, the PAI strategies are adjusted in relation to the acquisition wave to make farm integration less costly. These adjustments are reflected in acquired farms' greater resource allocation toward cash crop production, smaller differences from non-acquired farms regarding investments in variable inputs, divestment of fixed assets and labor and substitution with growing third-party services as well as less intensive land accumulation.

\subsection{Acquisition outcomes: profits, performance and organic growth}

Farm-level profits in crop production (measured both in absolute and normalized terms) generally show positive dynamics starting from $\mathrm{t}+1$ or $\mathrm{t}+2$ after an acquisition. In early post-acquisition years, the farms acquired during the acquisition wave demonstrate lower profits than non-acquired farms. However, in $\mathrm{t}+3$ and $t+4$, they start outperforming the farms overtaken before and after the acquisition wave. The development of absolute values of farm profits in animal production is rather inconclusive, while profit margins show statistically significantly higher growth only for the farms acquired before the acquisition wave.

Acquired farms are more likely to demonstrate higher productivity than non-acquired farms. In particular, crop production per hectare and per employee is statistically significantly higher than that on non-acquired farms. Capital productivity in both animal and crop production is statistically significantly higher only for the farms overtaken during the acquisition wave. The other performance measures returned mainly statistically insignificant differences. Generally, partial productivities and yields are higher on the farms acquired during the acquisition wave.

Finally, acquisitions positively affect the post-acquisition organic growth of acquired farms (Figure 4). However, the differences between acquired and non-acquired farms are on average 3-4 times lower in the 

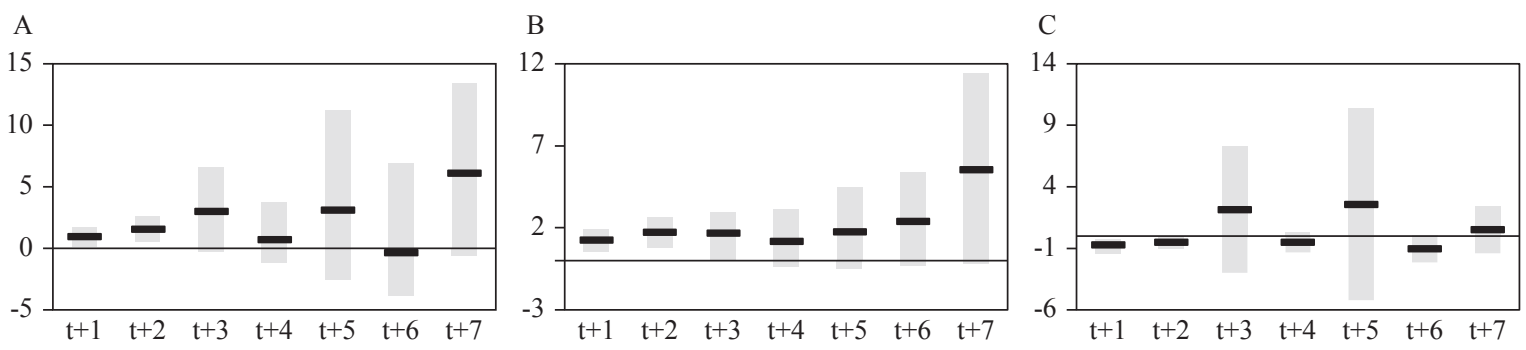

Figure 4. Post-acquisition organic growth, in million UAH. (A) total production, (B) crop production and (C) animal production. Black dashes represent average treatment effects on the treated and grey bars represent $95 \%$ confidence intervals. Estimations were carried out for the whole sample, i.e. acquisitions made during 2008-2015.

case of acquisition-wave takeovers. Crop production is the major driver of organic growth at the farm level. Growth in crop production is observed starting from $t+1$ and shows an ascending dynamic. Insignificant differences between acquired and non-acquired farms with regard to total production growth on the farms overtaken after the acquisition wave result from simultaneous growth in crop production and decline in animal production.

\subsection{Post-acquisition profit/growth categorization}

In accordance with our categorization approach described in the methods section, we present below the interpretation of the estimations regarding the variables that operationalize the farms' pre-acquisition characteristics, PAI instruments and post-acquisition outcomes. The tables with the estimation results are presented in the supplementary materials (Tables S11-S13) due to their extensiveness. The medians are calculated for all seven groups; however, we focus on the interpretation of the most distinct categories, including 'low effect', 'star effect' and 'extensive size growth' acquisitions as well as the farms that were 'merged or liquidated' after an acquisition.

According to Table S11, 'star effect acquisitions' (group 5) include farms that are of average size compared to other acquired farms and have a comparatively low share of crop production, low crop productivity, low land rent price, moderate use of inputs and third-party services, low depreciation and close-to-zero profit margins before acquisitions. To achieve a 'star effect', agroholdings perform a rapid integration of acquired farms using a combination of instruments. In particular, the PAI of the 'star effect' farms involve greater resource allocation toward crop production through putting more available land into operation. The 'star effect' is also achieved through investments in variable inputs, thus increasing material costs and capital and labor divestments with simultaneous growth in the use of third-party services (Table S12). Interestingly, the development of material costs, land area and labor demonstrate an inverted U-shaped form with a peak in $\mathrm{t}+3$. A similar development takes place with regard to productivity, profits and organic growth, with these indicators growing by $\mathrm{t}+3$ and decreasing afterwards (Table S13). Although the growth rates of these outcome variables in $\mathrm{t}+5$ are lower than those in $\mathrm{t}+3$, the farms in the 'star effect' group still show highly positive acquisition outcomes in $\mathrm{t}+5$.

The 'extensive size growth' farms (group 6) have similar pre-acquisition features as the 'star effect' acquisitions and are characterized by low crop productivity, substantial animal production shares, low land rent price, moderate input and third-party service use, low depreciation and close-to-zero profit margins. However, compared with the 'star effect' group, the farms of the 'extensive size growth' group were small, with a median value of total production of UAH 0.971 million and a median value of land of 979 ha (Table S11). Most likely, the small size is the reason why these farms experienced a significant expansion of land area since agroholdings directed their efforts to reach a minimum efficiency scale of acquired farms. Accordingly, we observe high different cost type growth (Table S12), enormous organic growth and moderate but positive profit and productivity development (Table S13) in this group of farms. 
'Merged or liquidated' farms are of medium size based on the production value but small in terms of land area. They are highly productive, show specialized crop production and are characterized by high land rent payments, a high third-party service share and low but positive profit margins (Table S11). In the course of PAI, this group of farms experienced some labor divestment in $t+1$ while its use of other resources changed insignificantly.

Finally, the 'low effect' acquired farms were already large, productive and profitable before an acquisition (Table S11). Their integration (Table S12) involved divestment of land and cutting of production costs, such as materials and labor as well as substitution of services for capital (depreciation). At the same time, the 'low effect' group paid increasingly higher land rents. However, the post-acquisition outcomes for this group of farms were rather negative, and they experienced reductions in size, productivity and profitability (Table S13).

In addition to post-acquisition profit/growth categorization, we also generated transition matrixes to assess how farms move between the groups in periods $t+3$ and $t+5$ (Table 2). The results suggest that one-third of farms with the 'star effect' after an acquisition retained their status in period $t+5$. Alternatively, the 'stareffect' farms transition to the 'profit growth-oriented', 'medium effect' or 'size growth-oriented' groups but not to the 'low effect' group. Similarly, the 'low effect' acquisitions in $\mathrm{t}+3$ are unlikely to become the 'star effect' acquisitions by $\mathrm{t}+5$. Rather, they tend to move to the 'merged or liquidated' or 'medium effect' groups.

Moreover, we observe that the 'profit growth-oriented' farms are more likely to retain their positions while the 'medium effect' and 'size growth-oriented' farms have a high risk of ending up in the 'low effect' group.

\section{Discussion and conclusions}

The empirical literature on the scope of the firm and its performance implications has paid little attention to the processes of M\&A in the sector of primary agriculture. Such work is particularly applicable to agriculture in post-Soviet transition economies, where the implications of ongoing farm consolidation and integration by so-called agroholdings remain underresearched. We address this gap by examining the processes and outcomes of farm acquisitions by Ukrainian agroholdings from a dynamic perspective.

Generally, our results demonstrate that acquisition by an agroholding has a positive effect on farm growth, profitability and productivity. However, the variation in this effect is subject to the magnitude of the use of specific PAI instruments, which in turn depends on factors that include acquisition timing and farm preacquisition characteristics.

Table 2. Number of farms that transition between groups in $\mathrm{t}+3$ and $\mathrm{t}+5$.

\begin{tabular}{|c|c|c|c|c|c|c|c|c|}
\hline & & \multicolumn{7}{|c|}{ Group in $\mathbf{t}+5$} \\
\hline & & $\begin{array}{l}1- \\
\text { 'low effect' }\end{array}$ & $\begin{array}{l}2- \\
\text { 'profit growth- } \\
\text { oriented' }\end{array}$ & $\begin{array}{l}3- \\
\text { 'medium } \\
\text { effect' }\end{array}$ & $\begin{array}{l}4- \\
\text { 'size-growth } \\
\text { oriented' }\end{array}$ & $\begin{array}{l}5- \\
\text { 'star effect' }\end{array}$ & $\begin{array}{l}6- \\
\text { 'extensive } \\
\text { size growth' }\end{array}$ & $\begin{array}{l}7- \\
\text { 'merged or } \\
\text { liquidated' }\end{array}$ \\
\hline \multirow{6}{*}{ 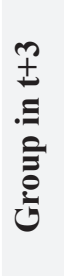 } & 1 & 12 & 7 & 10 & 4 & 2 & 2 & 11 \\
\hline & 2 & 2 & 23 & 5 & 0 & 2 & 1 & 6 \\
\hline & 3 & 13 & 3 & 25 & 6 & 6 & 2 & 7 \\
\hline & 4 & 12 & 0 & 8 & 16 & 4 & 5 & 4 \\
\hline & 5 & 1 & 8 & 10 & 9 & 17 & 2 & 2 \\
\hline & 6 & 0 & 1 & 0 & 3 & 1 & 11 & 1 \\
\hline
\end{tabular}


Regarding acquisition timing, our results are consistent with existing predictions (Harford, 2005; RhodesKropf and Viswanathan, 2004) and show that farm takeovers made during the acquisition wave may have some negative welfare effects in the short run. Acquired farms experience nonrecoverable divestments of labor and fixed assets, but they grow in terms of land area (although with some delay). Moreover, this development underscores that size expansion through farmland accumulation should be prioritized during the acquisition wave. Our results partly prove this by demonstrating that agroholdings try to secure the acquired land by paying higher land rents than non-agroholding farms, even during the acquisition wave. In addition to slow gradual lease-based land accumulation enabled by existing policies, such as the moratorium on farmland sales and absence of restrictions on land leases durations, we believe that these policies also incentivize rapid farm consolidation-oriented growth and acquisition waves by agroholdings. According to the transaction cost economics, in farm asset portfolios, it is much more efficient to purchase a whole farm for which the land rent contracts have been concluded than to individually conclude land rent contracts with thousands of smallholder landowners. This argument extends M\&A desperation theory (Kim et al., 2011) by showing that an institutional environment can make firms depend on growth via acquisitions.

Regarding the effects of farm pre-acquisition characteristics, we observe that major improvements on acquired farms are due to significant inefficiencies that existed on those farms prior to an acquisition. The lowest growth 'low effect' farms in our sample are the farms that were large, productive and profitable prior to being acquired. In turn, the highest-growth farms in terms of both size and profits were relatively small, unproductive and slightly profitable before an acquisition. The strategies that agroholdings use to enhance the growth of such farms include greater emphasis on crop production, heavy intensification and increased crop production productivity by improving the storage infrastructure (increase in SG\&A costs) and expanding the land in operation to achieve a 'minimum efficiency scale' (Juvančič, 2005). Interestingly, the latter can be achieved in two ways. First, agroholdings can start recultivating the previously unused land available on acquired farms because they possess the necessary resources to farm larger areas (Meyfroidt et al., 2016). Second, as our results suggest, agroholdings make use of productive and large 'low effect' farms by merging them with non-productive and small farms to establish consolidated farming complexes of a more efficient scale.

To summarize, the process of PAI in agroholdings is primarily driven by the need to deal with existing inefficiencies on acquired farms and thus is subject to those inefficiencies. Regarding the effect of acquisition timing on the type of PAI instruments used, it is evident that: (1) major resource redeployment takes place in $\mathrm{t}+1$ while agroholdings subsequently only tend to maintain the level of resources redeployed in $\mathrm{t}+1$; (2) resource allocation takes place in early post-acquisition years before, during and after the acquisition wave; (3) greater investment in variable inputs is typical of pre-wave acquisitions while investment in infrastructure (SG\&A costs) occurs generally throughout the whole period of acquisitions; and (4) divestment (of labor and fixed assets) occurs at early post-acquisition stages for the farms acquired during the wave and less so for the farms acquired before the wave.

The above changes occur predominantly with respect to crop production. As our findings indicate, the use of PAI instruments is significantly less pronounced in animal production. Being simultaneously labor and capital intensive, animal production offers little opportunity for rapid returns. In particular, this holds under the circumstances of highly elastic demand and squeezed prices on domestic markets as well as frequent import restrictions from major trade partners, primarily the Eurasian Economic Community (Liefert and Liefert, 2015). Therefore, the agroholdings that acquire farms with mixed crop-animal specialization involve the gradual reorientation of the specialization of newly acquired farms toward more crop production. This finding is consistent with the notion of the diversification strategy for declining industries described by Anand and Singh (1997), who postulate that diversifying out of such industries involves the transfer of resources and capabilities to alternative markets. 
Finally, in line with the conclusions of Davidsson et al. (2009) and Hitt et al. (1991), our results show that sustainable growth requires securing sufficient profitability. On the farm level, the initially profit-oriented farms are more capable of sustaining organic growth in the long run after an acquisition than the farms that prioritize size expansion. We extend this vision by showing that such sustainably growing farms also use a broader scope of PAI instruments, including resource allocation, investment in variable inputs and redeployment of resources from an acquirer to a target.

One limitation of our study is that it does not directly inquire about the role of particular PAI instruments or their combinations or a particular strategic growth orientation (i.e. profitable or size growth) in achieving successful and sustainable post-acquisition outcomes. We perceive this gap as an avenue for future research that can be addressed by applying different regression techniques to our data. The contribution of the present study is the dynamic perspective applied to farm-level post-acquisition processes and outcomes in the context of a transition economy. Our study also provides useful insights into sector- and time-specific farm growth strategies by distinguishing between animal and crop production as well as by considering acquisition timing.

\section{Supplementary material}

Supplementary material can be found online at https://doi.org/10.22434/IFAMR2020.0188

Table S1. Operationalization of the variables and grouping.

Table S2. Descriptive statistics of the covariates, 2005-2014.

Table S3. Descriptive statistics of the outcome variables, change in $\mathrm{t}+1$ comparing to $\mathrm{t}-1,2008-2016$.

Table S4. The results of the logistic regressions.

Table S5. The result of the factor analysis estimation.

Table S6. Standardized mean differences of covariates in total production models.

Table S7. Standardized mean differences of covariates in crop production models.

Table S8. Standardized mean differences of covariates in animal production models.

Table S9. Results of the overlap tests, 2008-2015.

Table S10. The results of the NNM analysis (ATET).

Table S11. Median values and standard deviations of farms' pre-acquisition characteristics by groups.

Table S12. Median values of farms' PAI in crop production by groups.

Table S13. Median values of farm-level acquisition outcomes by groups.

\section{Acknowledgements}

The authors are grateful to the International Competence Center on Large Scale Agriculture (LaScalA) funded by the Leibniz Association (Germany). The authors highly acknowledge two anonymous referees and the Editor of this journal for their helpful suggestions to improve the manuscript. The authors thank YouControl, the analytical system for compliance, market analysis, business intelligence, and investigations, for providing access to their system.

\section{References}

Abadie, A. and G.W. Imbens. 2002. Simple and bias-corrected matching estimators for average treatment effects. NBER Technical Working Paper 283. National Bureau of Economic Research, Cambridge, MA, USA.

Abadie, A. and G.W. Imbens. 2006. Large sample properties of matching estimators for average treatment effects. Econometrica 74(1): 235-267.

Abadie, A. and G.W. Imbens. 2011. Bias-corrected matching estimators for average treatment effects. Journal of Business and Economic Statistics 29(1): 1-11.

Abadie, A., D. Drukker, J.L. Herr and G.W. Imbens. 2004. Implementing matching estimators for average treatment effects in Stata. Stata Journal 4(3): 290-311. 
Anand, J. and H. Singh. 1997. Asset redeployment, acquisitions and corporate strategy in declining industries. Strategic Management Journal 18: 99-118.

Arndt, C. and A. Mattes. 2010. Cross-border mergers and acquisitions of multinational firms. new firm-level evidence. IAW Diskussionspapiere, Institute for Applied Economic Reasearch (IAW), Tuebingen, Germany.

Balmann, A., J. Curtiss, T. Gagalyuk, V. Lapa, A. Bondarenko, K. Kataria and F. Schaft. 2013. Productivity and efficiency of ukrainian agricultural enterprises. Agriculture Policy Report (APD/APR/06/2013), German-Ukrainian Agropolitical Dialog, Kyiv, Ukraine.

Balsvik, R. and S. Haller. 2010. Picking 'lemons' or picking 'cherries'? Domestic and foreign acquisitions in Norwegian manufacturing. Scandinavian Journal of Economics 112(2): 361-387.

Bodner, J. and L. Capron. 2018. Post-merger integration. Journal of Organization Design 7(3): 1-20.

Buduru, B. and M. Brem. 2007. Transaction costs, strategic interaction, and farm restructuring. Agricultural Economics 37(1): 67-80.

Byerlee, D. and K. Deininger. 2013. Growing resource scarcity and global farmland investment. Annual Review of Resource Economics 5(1): 13-34.

Capron, L. 1999. The long-term performance of horizontal acquisitions. Strategic Management Journal 20(11): 987-1018.

Capron, L. and W. Mitchell. 1997. Outcomes of international telecommunications acquisitions: analysis of four cases with implications for acquisitions theory. European Management Journal 15(3): 237-251.

Capron, L., P. Dussauge and W. Mitchell. 1998. Resource redeployment following horizontal acquisitions in Europe and North America. Strategic Management Journal 19: 631-661.

Capron, L., W. Mitchell and A. Swaminathan. 2001. Asset divestiture following horizontal acquisitions: a dynamic view. Strategic Management Journal 22(9): 817-844.

Chaddad, F. and M. Boland. 2009. Strategy-structure alignment in the world coffee industry: the case of Cooxupe. Review of Agricultural Economics 31(3): 653-665.

Chaddad, F. and V. Valentinov. 2017. Agency costs and organizational architecture of large corporate farms: evidence from Brazil. International Food and Agribusiness Management Review 20(2): 201-220.

Coad, A. 2009. The growth of firms. a survey of theories and empirical evidence. Edward Elgar Publishing Limited, Cheltenham, UK.

Davidsson, P., P. Steffens and J. Fitzsimmons. 2009. Growing profitable or growing from profits: putting the horse in front of the cart? Journal of Business Venturing 24(4): 388-406.

Dehejia, R.H. and S. Wahba. 1999. Causal effects in nonexperimental studies: reevaluating the evaluation of training programs. Journal of the American Statistical Association 94: 1053-1062.

Dehejia, R.H. and S. Wahba. 2002. Propensity score-matching methods for nonexperimental causal studies. The Review of Economics and Statistics 84(1): 151-161.

Deininger, K. and D. Byerlee. 2012. The rise of large farms in land abundant countries: do they have a future? World Development 40(4): 701-714.

Deininger, K., D. Nizalov and S. Singh. 2018. Determinants of productivity and structural change in a large commercial farm environment: evidence from Ukraine. The World Bank Economic Review 32(2): 287-306.

Delmar, F. 1997. Measuring growth: methodological considerations and empirical results. In: R. Donckels and A. Miettinen (eds.) Entrepreneurship and SME research: on its way to the next millennium. Ashgate, Aldershot, UK, pp. 199-216.

Ebneth, O. and L. Theuvsen. 2007. Large mergers and acquisitions of European brewing groups - event study evidence on value creation. Agribusiness 23(3): 377-406.

Epshtein, D., K. Hahlbrock and J. Wandel. 2013. Why are agroholdings so pervasive in Russia's Belgorod Oblast'? Evidence from case studies and farm-level data. Post-Communist Economies 25(1): 59-81.

FiBL. 2016. The basics of soil fertility. Shaping our relationship to the soil. Research Institute of Organic Agriculture FiBL, Frick, Switzerland. Available at: https://www.fibl.org/de/shop/4002-soil-fertility.html

Filippaios, F. and R. Rama. 2011. Cultural distance and internationalization: the world's largest food and drink multinationals. Agribusiness 27(4): 399-419. 
Francksen, T., M. Hagemann and U. Latacz-Lohmann. 2012. Growth of milk production in German dairy farms: an empirical study based on event history analysis. Agricultural Economics 43(6): 671-685.

Gagalyuk, T. 2017. Project review: International Competence Center on large scale agriculture at the Leibniz Institute of Agricultural Development in Transition Economies. Journal of Applied Management and Investments 6(2): 147-150.

Gagalyuk, T. and V. Valentinov. 2019. Agroholdings, turbulence, and resilience: the case of Ukraine. Journal of East European Management Studies 24(3): 484-496.

Gagalyuk, T., V. Valentinov and F. Schaft. 2018. The corporate social responsibility of Ukrainian agroholdings: the stakeholder approach revisited. Systemic Practice and Action Research 31(6): 675-698.

Glazerman, S., D.M. Levy and D. Myers. 2003. Nonexperimental versus experimental estimates of earnings impacts. The Annals of the American Academy of Political and Social Science 589: 63-93.

Graebner, M.E., K.H. Heimeriks, Q.N. Huy and E. Vaara. 2017. The process of postmerger integration: a review and agenda for future research. Academy of Management Annals 11(1): 1-32.

Graubner, M., I. Ostapchuk and T. Gagalyuk. 2021. Agroholdings and land rental markets: a spatial competition perspective. European Review of Agricultural Economics 48(1): 158-206.

Greifer, N. 2020. Matching methods. Available at: https://cran.r-project.org/web/packages/MatchIt/vignettes/ matching-methods.html

Hahlbrock, K. and H. Hockmann. 2011. Influence of the integration of agroholdings with Russian farms on total factor productivity and its subcomponents. In: 51. Jahrestagung Der GEWISOLA „Unternehmerische Landwirtschaft Zwischen Marktanforderungen Und Gesellschaftlichen Erwartungen'. 28-30 September 2011, Halle, Germany, pp. 12.

Hahlbrock, K. and H. Hockmann. 2012. Does group affiliation increase productivity and efficiency in Russia's agriculture? Evidence from agroholdings in the Oblast Belgorod. In: XII International Scientific Conference on the Problems of Economic and Society Development (XII Международная Научная Конференция По Проблемам Развития Экономики и Общества). Moscow, Russia, pp. 100-109.

Haleblian, J., Cynthia E.D., G. McNamara, M.A. Carpenter and R.B. Davison. 2009. Taking stock of what we know about mergers and acquisitions: a review and research agenda. Journal of Management 35(3): 469-502.

Hallam, A. 1991. Economies of size and scale in agriculture: an interpretive review of empirical measurement. Review of Agricultural Economics 13(1): 155-172.

Harford, J. 2005. What drives merger waves? Journal of Financial Economics 77(3): 529-560.

Haspeslagh, P. and D. Jemison. 1991. Making acquisitions work. Free Press, New York, NY, USA.

Havlin, J. and R. Heiniger. 2020. Soil fertility management for better crop production. Agronomy 10(9): 1-5.

Herger, N. 2008. Cross-border acquisitions in the global food sector. European Review of Agricultural Economics 35(4): 563-587.

Hermans, F.L.P., F.R. Chaddad, T. Gagalyuk, S. Senesi and A. Balmann. 2017. The emergence and proliferation of agroholdings and mega farms in a global context. International Food and Agribusiness Management Review 20(2): 175-186.

Hitt, M., R. Hoskisson, R. Ireland and J. Harrison. 1991. Effects of acquisitions on R\&D inputs and outputs. Academy of Management Journal 34(3): 693-706.

Hockmann, H., J. Wandel and A. Nedoborovskyy. 2005. Agroholdings in Russia: breaking the vicious circle? In: $94^{\text {th }}$ EAAE seminar 'From household to firms with independent legal status: the spectrum of institutional units in the development of European agriculture'. 9-10 April 2005. Ashford, UK, pp. 11.

Hockmann, H., R. Bokusheva and I. Bezlepkina. 2007. Agroholdings membership: does that make a difference in performance? In: $102^{\text {th }}$ EAAE seminar 'Superlarge farming companies: emergence and possible impacts'. 17-18 May 2007. Moscow, Russia, pp. 27.

Imbens, G.W. and J.M. Wooldridge. 2009. Recent developments in the econometrics of program evaluation. Journal of Economic Literature 47(1): 5-86.

Interfax. 2018. Spark. Verification, analysis and monitoring of companies. Interfax, Frankfurt, Germany. Available at: https://spark-interfax.com/ 
Juvančič, L. 2005. Characteristics of structural adjustment of agricultural holdings in Slovenia. In: Pöchtrager, S. (ed.) Jahrbuch Der Österreichischen Gesellschaft Für Agrarökonomie. Wien, Österreich, pp. 311-329.

Karim, S. and L. Capron. 2016. Reconfiguration: adding, redeploying, recombining and divesting resources and business units. Strategic Management Journal 37(13): 1-20.

Khandker, S.R., G.B. Koolwal and H.A. Samad. 2010. Handbook on impact evaluation. Quantitative methods and practices. The World Bank, Washington, DC, USA.

Kim, J.J., J. Haleblian and S. Finkelstein. 2011. When firms are desperate to grow via acquisition: the effect of growth patterns and acquisition experience on acquisition premiums. Administrative Science Quarterly 56(1): 26-60.

Klepac, V. and D. Hampel. 2017. Predicting financial distress of agriculture companies in EU. Agricultural Economics (Zemédělská Ekonomika) 63(8): 347-355.

Klimek, B. and H.O. Hansen. 2017. Food industry structure in Norway and Denmark since the 1990s: path dependency and institutional trajectories in Nordic food markets. Food Policy 69: 110-122.

Koester, U. 2005. A revival of large farms in eastern Europe - how important are institutions? Agricultural Economics 32, Suppl. 1: 103-113.

Kogut, B. and U. Zander. 1992. Knowledge of the firm, combinative capabilities, and the replication of technology. Organization Science 3(3): 383-397.

KPMG. 2019. Ukrainian M\&A review 2018. KPMG Ukraine, Kyiv, Ukraine. Available at: https://assets. kpmg/content/dam/kpmg/ua/pdf/2019/02/Ukrainian-MA-Review-report-2018-EN.pdf

Kruskal, W.H. and W.A. Wallis. 1952. Use of ranks in one-criterion variance analysis. Journal of the American Statistical Association 47(260): 583-621.

Lamprinakis, L. and M. Fulton. 2011. Does acquisition of a cooperative generate profits for the buyer? The dairyworld case. Agricultural Economics 42, Suppl. 1: 89-100.

Lapa, V., T. Gagalyuk and I. Ostapchuk. 2015. The emergence of agroholdings and patterns of land use in Ukraine. In: A. Schmitz and W. Meyers (eds.) Transition to agricultural market economies: the future of Kazakhstan, Russia and Ukraine. CABI, Wallingford, UK, pp. 102-110.

Lerman, Z., D. Sedik, N. Pugachov and A. Goncharuk. 2007. Rethinking agricultural reform in Ukraine. Studies on the agricultural and food sector in Central and Eastern Europe. Vol. 38. IAMO, Halle (Saale), Germany.

Liefert, W.M. and O. Liefert. 2015. Russia's potential to increase grain production by expanding area. Eurasian Geography and Economics 56(5): 505-523.

Lindner S. and McConnell K. 2019. Difference-in-differences and matching on outcomes: a tale of two unobservables. Health Services and Outcomes Research Methodology 19(2-3): 127-144.

Mamonova, N. 2015. Resistance or adaptation? Ukrainian peasants' responses to large-scale land acquisitions. The Journal of Peasant Studies 42(3-4): 607-634.

Matyukha, A., P. Voigt and A. Wolz. 2015. Agro-holdings in Russia, Ukraine and Kazakhstan: temporary phenomenon or permanent business form? Farm-level evidence from Moscow and Belgorod regions. Post-Communist Economies 27(3): 370-394.

McKelvie, A. and J. Wiklund. 2010. Advancing firm growth research: a focus on growth mode instead of growth rate. Entrepreneurship Theory and Practice 34(2): 261-288.

Meyfroidt, P., F. Schierhorn, A.V. Prishchepov, D. Müller and T. Kuemmerle. 2016. Drivers, constraints and trade-offs associated with recultivating abandoned cropland in Russia, Ukraine and Kazakhstan. Global Environmental Change 37: 1-15.

Muehlfeld, K., U. Weitzel and A. Van Witteloostuijn. 2011. Mergers and acquisitions in the global food processing industry in 1986-2006. Food Policy 36(4): 466-479.

Nelson, R.R. and S.G. Winter. 1982. An evolutionary theory of economic change. Harvard University Press, Cambridge, MA, USA.

Nguyen, S.V. and M. Ollinger. 2006. Mergers and acquisitions and productivity in the U.S. meat products industries: evidence from the micro data. American Journal of Agricultural Economics 88(3): 606-616.

Nguyen, S.V. and M. Ollinger. 2009. Mergers and acquisitions, employment, wages, and plant closures in the U.S. meat product industries. Agribusiness 25(1): 70-89. 
Ostapchuk, I., T. Gagalyuk, D. Epshtein and A. Dibirov. in press. What drives the acquisition behavior of agroholdings? Performance analysis of agricultural acquisition targets in Northwest Russia and Ukraine. International Food and Agribusiness Management Review. https://doi.org/10.22434/ IFAMR2020.0081

Ostapchuk, I., M. Graubner and T. Gagalyuk. 2019. The potential of Ukrainian crop production: profit and yield-based projections. In: Visionen Für Eine Agrar-Und Ernährungspolitik Nach 202. Schriften Der Gesellschaft Für Wirtschafts- Und Sozialwissenschaften Des Landbaus, Bd. 54. 12-14 September 2018. Münster, Germany, pp. 3-16.

Palmer, D.A., P.D. Jennings and X. Zhou. 1993. Late adoption of the multidivisional form by large U.S. corporations: institutional, political, and economic accounts. Administrative Science Quarterly 38(1): 100-131.

Penrose, E. 1995. The theory of the growth of the firm, $2^{\text {nd }}$ edition. Oxford University Press, New York, NY, USA.

Petrick, M., J. Wandel and K. Karsten. 2012. Economic and social impacts of recent agro- investment in Kazakhstan's Grain Region. In: Annual World Bank Conference on Land and Poverty. 23-26 April 2012. Washington, DC, USA. pp. 34.

Petrick, M., J. Wandel and K. Karsten. 2013. Rediscovering the virgin lands: agricultural investment and rural livelihoods in a Eurasian frontier area. World Development 43: 164-179.

Piet, L., L. Latruffe, C. Le Mouel and Y. Desjeux. 2012. How do agricultural policies influence farm size inequality? The example of France. European Review of Agricultural Economics 39(1): 5-28.

Ramezani, C.A., L.A. Soenen and A.R. Jung. 2002. Growth, corporate profitability, and shareholder value creation. Financial Analysts Journal 62(6): 56-67.

Renneboog, L., P.G. Szilagyi and C. Vansteenkiste. 2017. Creditor rights, claims enforcement, and bond performance in mergers and acquisitions. Journal of International Business Studies 48(2): 174-194.

Rhodes-Kropf, M. and S. Viswanathan. 2004. Market valuation and merger waves. Journal of Finance 59(6): 2685-2718.

Rizov, M. and E. Mathijs. 2003. Farm survival and growth in transition economies: theory and empirical evidence from Hungary. Post-Communist Economies 15(2): 227-242.

Rosenbaum, P.R. and D.B. Rubin. 1983. The central role of the propensity score in observational studies for causal effects. Biometrika 70(1): 41-55.

Salis, S. 2008. Foreign acquisition and firm productivity: evidence from Slovenia. World Economy 31(8): 1030-1048.

Schroeter, J., A. Azzam and J.D. Aiken. 2006. Anti-corporate farming laws and industry structure: the case of cattle feeding. American Journal of Agricultural Economics 88(4): 1000-1014.

Shapiro, D., R.D. Bollman and P. Ehrensaft. 1987. Farm size and growth in Canada. American Journal of Agricultural Economics 69(2): 477-483.

Shepherd, D. and J. Wiklund. 2009. Are we comparing apples with apples or apples with oranges? Appropriateness of knowledge accumulation across growth studies. Entrepreneurship Theory and Practice 33(1): 105-123.

Shrivastava, P. 1986. Postmerger integration. Journal of Business Strategy 7(1): 65-76.

Steigenberger, N. 2017. The challenge of integration: a review of the M\&A integration literature. International Journal of Management Reviews 19(4): 408-431.

Stiebale, J. and M. Trax. 2011. The effects of cross-border M\&As on the acquirers' domestic performance: firm-level evidence. Canadian Journal of Economics 44(3): 957-990.

Stuart, E.A. 2010. Matching methods for causal inference: a review and a look. Statistical Science 25(1): 1-21.

Sumner, D.A. 2014. American farms keep growing: size, productivity, and policy. Journal of Economic Perspectives 28(1): 147-166.

Tao H. and C. Xie. 2015. A case study of Shuanghui International's strategic acquisition of Smithfield Foods. International Food and Agribusiness Management Review 18(1): 145-166.

Teerikangas, S. and P. Very. 2006. The culture-performance relationship in M\&A: from yes/no to how. British Journal of Management 17: 31-48. 
UCAB. 2019. LFM (large farm management) book. Ukrainian Agribusiness Club (UCAB), Kyiv, Ukraine. Available at: http://ucab.ua/en/lfm_book (in Ukrainian)

Vermeulen, F. and H. Barkema. 2001. Learning through acquisitions. Academy of Management Journal 44(3): 457-476.

Walther, S. 2014. Determinants of competitiveness of agriholdings and independent farms in Ukrainian arable production. Thünen Report No. 15. Braunschweig, Germany.

Wandel, J. 2011. Business groups and competition in post-Soviet transition economies: the case of Russian 'agroholdings'. Review of Austrian Economics 24(4): 403-450.

Weber, R. and C. Camerer. 2003. Cultural conflict and merger failure: an experimental approach. Management Science 49(4): 400-415.

Weiss, C.R. 1999. Farm growth and survival: econometric evidence for individual farms in upper Austria. American Journal of Agricultural Economics 81(1): 103-116.

Wolfe, M., S. Stressman and M. Manfredo. 2011. The acquisition of IBP by Tyson Foods in 2001: pre- and post-merger financial performance. American Journal of Agricultural Economics 93(2): 642-647.

YouControl. 2019. Business plan YouControl - a full profile of every business in Ukraine. YouControl, Kyiv, Ukraine. 